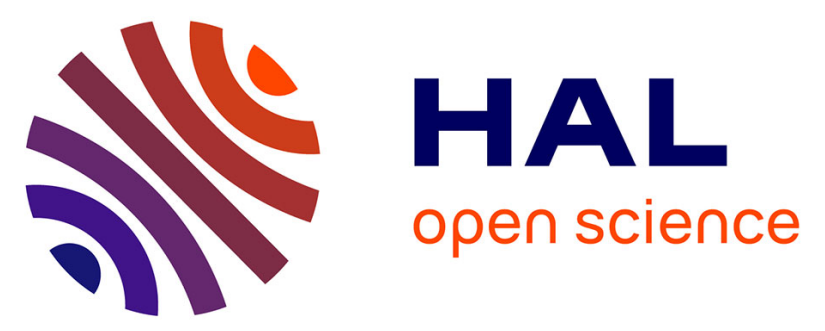

\title{
Experimental study of dynamical contact forces for tyre/road noise application
}

Julien Cesbron, Fabienne Anfosso-Lédée, Denis Duhamel, Honoré P. Yin, Donatien Le Houedec

\section{- To cite this version:}

Julien Cesbron, Fabienne Anfosso-Lédée, Denis Duhamel, Honoré P. Yin, Donatien Le Houedec. Experimental study of dynamical contact forces for tyre/road noise application. Acoustics 2008 Euronoise 2008, 2008, Paris, France. hal-01008196

\section{HAL Id: hal-01008196 https://hal.science/hal-01008196}

Submitted on 9 May 2018

HAL is a multi-disciplinary open access archive for the deposit and dissemination of scientific research documents, whether they are published or not. The documents may come from teaching and research institutions in France or abroad, or from public or private research centers.
L'archive ouverte pluridisciplinaire HAL, est destinée au dépôt et à la diffusion de documents scientifiques de niveau recherche, publiés ou non, émanant des établissements d'enseignement et de recherche français ou étrangers, des laboratoires publics ou privés. 

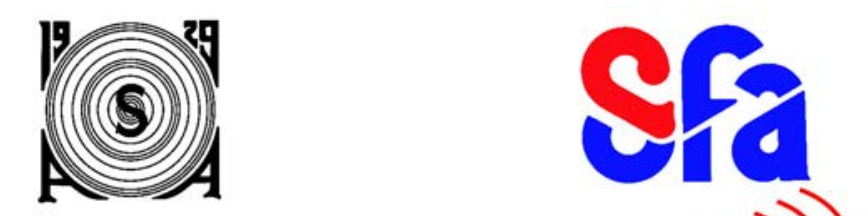

EAA
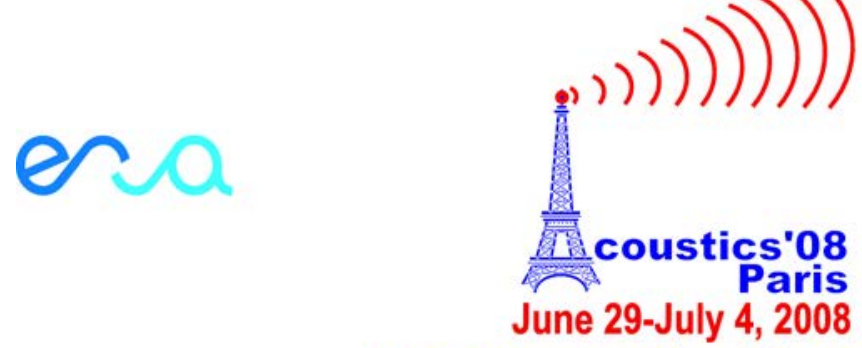

euronoise

www.acoustics08-paris.org

\section{Experimental study of dynamical contact forces for tyre/road noise application}

J. Cesbron ${ }^{\mathrm{a}}$, F. Anfosso-Ledee ${ }^{\mathrm{b}}$, D. Duhamel ${ }^{\mathrm{c}}$, H.P. Yin ${ }^{\mathrm{c}}$ and D. Le Houedec ${ }^{\mathrm{d}}$

a Université d'Evry - Val d'Essonne, Laboratoire de Mécanique d'Evry, EA3332, 40, rue du Pelvoux, 91020 Evry Cedex, France

${ }^{\mathrm{b}}$ Laboratoire Central des Ponts et Chaussées, BP 4129, 44341 Bouguenais Cedex, France ${ }^{\circ}$ ENPC, UR Navier, 6 et 8 Avenue Blaise Pascal, Cité Descartes, Champs sur Marne, 77455 Marne la Vallée, France

${ }^{d}$ Ecole Centrale de Nantes, GeM, 1 rue de la Noe, BP 92101, 44321 Nantes Cedex 3, France cesbron.julien@neuf.fr 
This paper deals with the experimental study of tyre/road contact forces in rolling conditions for tyre/road noise investigation. In situ measurements of contact forces were carried out for a slick tyre rolling on six different road surfaces at rolling speeds between $30 \mathrm{~km} / \mathrm{h}$ and $50 \mathrm{~km} / \mathrm{h}$. Contact stresses were measured at a sampling frequency of $10752 \mathrm{~Hz}$ using a single array of pressure sensitive cells placed both along and perpendicular to the rolling direction. The contact areas obtained during rolling were smaller than the one measured in statics. This could be due to an influence of the viscoelastic behavior of the rubber of the tyre tread during rolling. Additionally the root-mean-square of the resultant contact forces at various speeds was in the same order for a given road surface, while their spectra at various speeds were quite different. This could be explained by a spectral influence of the vibration of the tyre during rolling.

\section{Introduction}

Tyre/road noise has become a major issue in the struggle against road traffic noise [1]. It is generated by complex mechanisms which prediction needs a reliable description of tyre/road contact in rolling conditions.

Due to the difficulty to study the tyre/road contact experimentally, the investigations have been essentially focussed on the development of contact models. First a Winkler bedding model coupled with an orthotropic plate model of the tyre belt was developed in $[2,3]$. Alternative contact models are based on half-space assumptions for the tyre tread in the local area of tyre/road contact. The problem can be solved using a boundary element discretization $[4,5,6]$, analytical multi-asperity approaches $[7,8]$ or a mixed method taking the benefits of the analytical multi-asperity formulation for solving the boundary element problem more efficiently [9]. Finally, a finite element approach based on continuum mechanics was recently proposed in [10]. For all these models, only the normal contact forces are calculated and the friction is not taken into account. A recurrent hypothesis is also that the contact during rolling is evaluated from several contact patches in statics or quasi-statics for successive time steps. Moreover, the contact models are often validated by means of tyre vibration measurements in rolling conditions $[6,11]$ or spindle forces and moments measurements [12], but not from dynamical contact stresses measurements.

Thus the aim of this paper is the experimental study of tyre/road contact in rolling conditions for the validation of tyre/road contact models for noise prediction. The problem is here essentially investigated from a road perspective since the contact tests were performed in situ for a slick tyre rolling on different real road surfaces. Moreover only the normal contact stresses are measured. The contact forces measured at different speeds up to 50 $\mathrm{km} / \mathrm{h}$ are used to study both the influence of the road texture and the dynamical effects of the tyre such as viscoelasticity and vibrations on the contact.

\section{Measurement of contact forces}

\section{$2.1 \quad$ Pressure measurement system}

The normal stresses between the tyre and the road were measured at the contact interface using a real time acquisition (Fig. 1). A resistive sensor linked to a computer is divided in sensitive cells on which the electrical

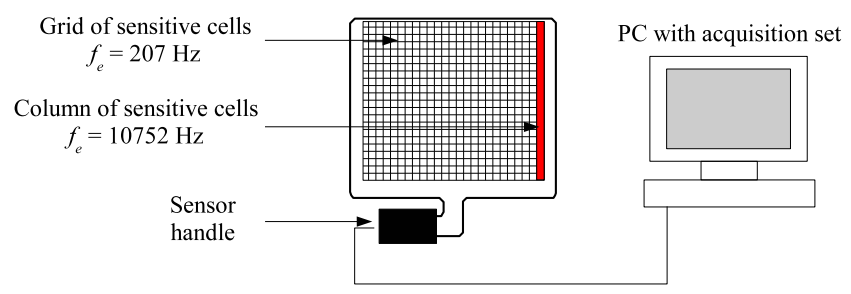

Figure 1: Contact pressure measurement system.

resistance varies proportionally to the contact pressure. It has an active area of $436 \times 368 \mathrm{~mm}^{2}$, is about $0.1 \mathrm{~mm}$ thick and is composed of $52 \times 44$ square cells of side $h=$ $8.38 \mathrm{~mm}$. Following the manufacturer [13], the measurement system was calibrated from the total load applied on the tyre measured on a weighting device. The overall system accuracy is $\pm 10 \%$ of the full pressure scale which varies between 0 and $0.86 \mathrm{MPa}$. The contact data can be acquired at $207 \mathrm{~Hz}$ on all the cells or at 10752 $\mathrm{Hz}$ on a single line of 44 cells (Fig. 1). In practice, the acquisition at $207 \mathrm{~Hz}$ was only used for static measurements whereas the rolling contact was studied on the single active line at $10752 \mathrm{~Hz}$.

\section{$2.2 \quad$ Road materials}

The measurement campaign was carried out on a test track in the Laboratoire Central des Ponts et Chaussées (LCPC, Nantes, France). Six real road surfaces were used for the tests as shown in Fig. 2. Two of them

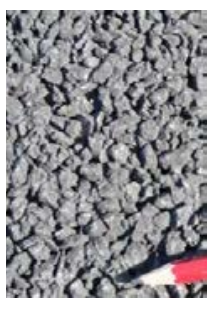

PA $0 / 6$

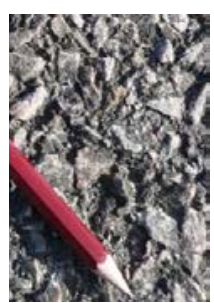

DAC 0/10 (old)

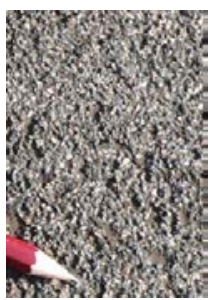

FSD $0.8 / 1.5$

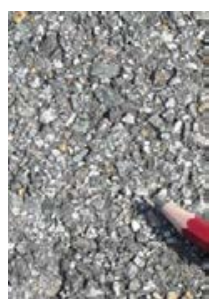

SA $0 / 4$

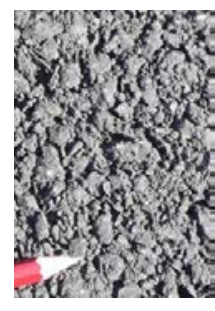

DAC 0/10 (new)

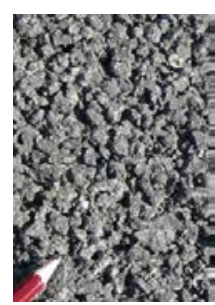

TL $0 / 6$
Figure 2: Upper view of the six tested road surfaces. 
are asphalt concretes with $6 \mathrm{~mm}$ maximum aggregate size: a Porous Asphalt (PA 0/6) and a semi-porous Thin Layer (TL 0/6). Two others are dense asphalt concretes with $10 \mathrm{~mm}$ maximum aggregate size: DAC 0/10 (new) and DAC 0/10 (old). The last two surfaces are a Fine Surface Dressing (FSD 0.8/1.5) and a Sand Asphalt (SA $0 / 4$ ) composed of small size aggregates.

\section{$2.3 \quad$ Experimental procedure}

The contact tests were performed on a passenger car fitted with two slick tyres on the rear wheels. Contact pressures were measured on the right rear slick tyre at a constant rolling speed (Fig. 3). The speed was ac-

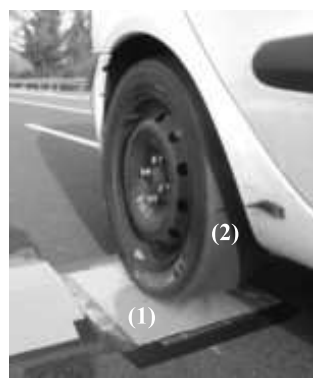

Figure 3: (1) Contact pressure sensor, (2) Slick tyre.

curately measured by a tachometer fixed to the wheel. It was limited to $50 \mathrm{~km} / \mathrm{h}$ for avoiding to damage the sensor but also for a correct analysis of the signals at low frequency.

The experimental procedure was devised in a way to study the possible effects of tyre dynamic on contact stresses during rolling. Thus for each road surface a contact patch was first measured in statics at $207 \mathrm{~Hz}$ on all cells. The sensor was taped on the road surface and calibrated. Then at the same position a dynamical test was performed at 30,40 and $50 \mathrm{~km} / \mathrm{h}$ with the active line of cells perpendicular to the rolling direction. These tests, denoted as "transverse tests", enabled to estimate dynamical contact patches. Next the active line of the sensor was placed along the rolling direction and a test was performed at 30,40 and $50 \mathrm{~km} / \mathrm{h}$. These measurements are denoted as "longitudinal tests" and give spectral informations on the contact forces.

\section{Contact forces analysis}

\subsection{Results from the "transverse tests"}

For the "transverse tests", the active line of the sensor is placed as shown in Fig. 4. The resultant contact force $F$ is then obtained by integrating the measured contact pressures $p_{i}(t)$ at time $t$ :

$$
F(t)=h^{2} \sum_{i=1}^{n_{c}} p_{i}(t)
$$

where $n_{c}=44$ is the number of cells. Noting $L_{y c}(t)$ the contact length in the transverse direction, then $F(t)$ represents the progressive loading of the tyre on the road within the surface of length $L_{y c}(t)$ and width $h$.

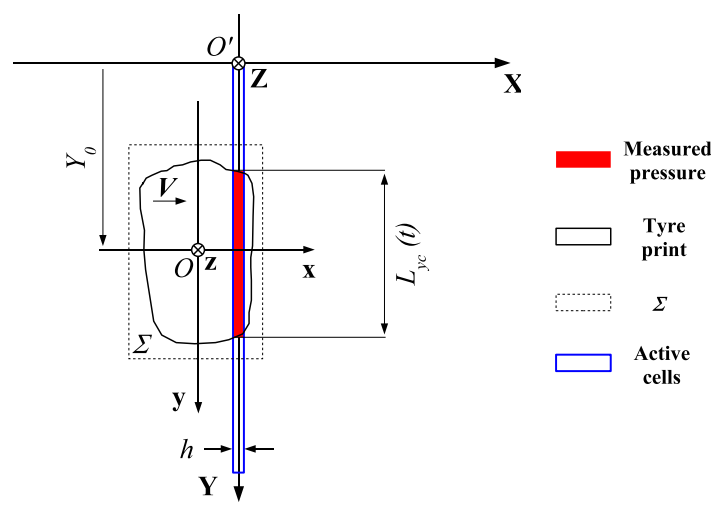

Figure 4: Cells position for the "transverse tests".

A measurement example is given in Fig. 5 for the DAC $0 / 10$ (new) at $30 \mathrm{~km} / \mathrm{h}$. It clearly shows the progressive loading and unloading of the tyre on the active line of cells during the "transverse tests".
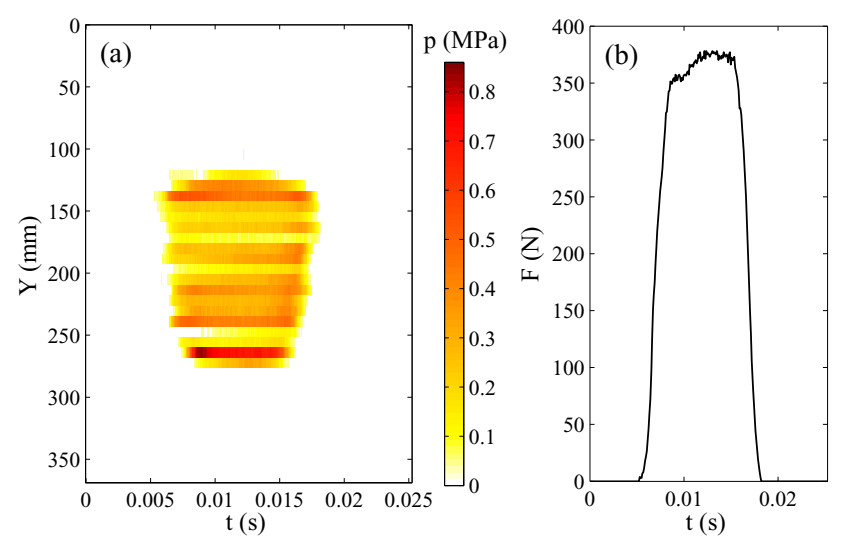

Figure 5: "Transverse test" for the DAC 0/10 (new): (a) Contact pressures, (b) Resultant contact force $F$.

From the measurements, the total contact area noted $A$ can be estimated by:

$$
A=V \int_{t_{1}}^{t_{2}} L_{y c}(t) d t
$$

where $t_{1}$ is the instant when the tyre begins to load on the line of cells and $t_{2}$ is the time when it leaves it. The contact patches measured in statics and at 30, 40 and $50 \mathrm{~km} / \mathrm{h}$ are given in Fig. 6 for the DAC 0/10 (new). It is noted that the dynamic contact prints are only estimated from the data measured on the active line and that the variation of texture in the rolling direction is not taken into account. Fig. 6 shows that the contact areas in rolling conditions are about $20 \%$ smaller than the one in statics. Moreover the dynamic contact areas are in the same order for the three rolling speeds. The decrease of the contact area is mainly observed in the longitudinal direction, while the length in the transverse direction remains almost constant between static and dynamic data. Similar results were observed for the other five road surfaces as it can be found in Table 1 . 


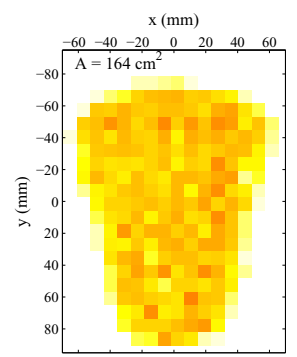

Static contact print

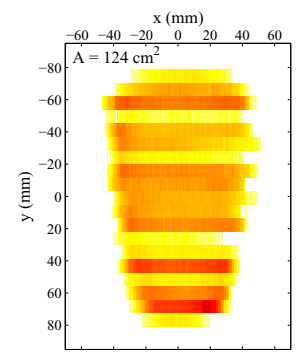

$\mathrm{V}=40 \mathrm{~km} / \mathrm{h}$

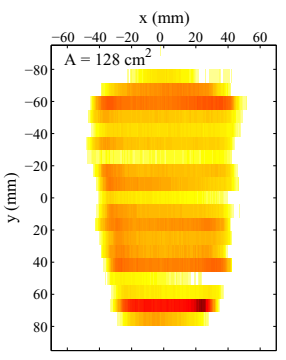

$\mathrm{V}=30 \mathrm{~km} / \mathrm{h}$

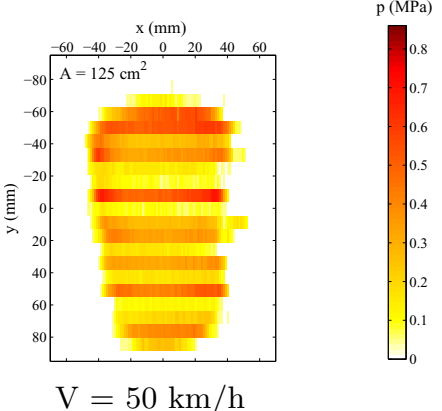

Figure 6: Contact patches measured in statics and at 30,40 and $50 \mathrm{~km} / \mathrm{h}$ for the DAC 0/10 (new).

\begin{tabular}{|c|c|c|c|c|}
\hline Surface & Statics & $30 \mathrm{~km} / \mathrm{h}$ & $40 \mathrm{~km} / \mathrm{h}$ & $50 \mathrm{~km} / \mathrm{h}$ \\
\hline PA & 156 & 123 & 123 & 122 \\
\hline FSD & 155 & 130 & 129 & 123 \\
\hline DAC (new) & 164 & 128 & 124 & 125 \\
\hline DAC (old) & 164 & 133 & 137 & 131 \\
\hline SA & 160 & 122 & 127 & 121 \\
\hline TL & 151 & 134 & 131 & 136 \\
\hline
\end{tabular}

Table 1: Contact area $A$ (in $\left.\mathrm{cm}^{2}\right)$ with rolling speed.

\subsection{Results from the "longitudinal tests"}

In the case of the "longitudinal tests", the active line of cells is placed as shown in Fig. 7. The resultant

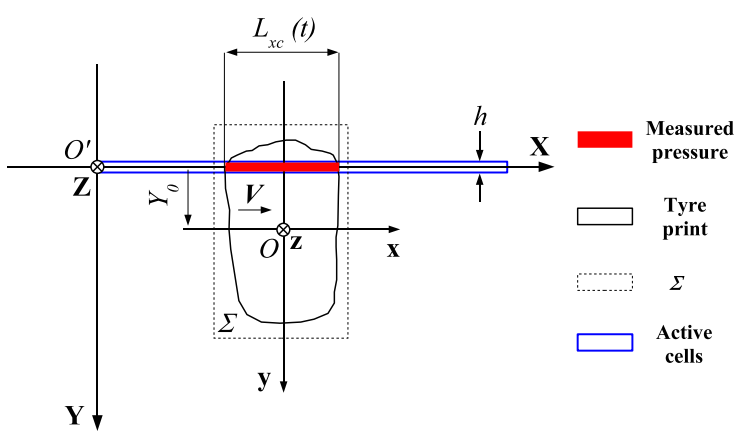

Figure 7: Cells position for the "longitudinal tests".

contact force $F$ is calculated by integrating the pressures as in Eq (1). This force is representative of the total load applied at each time step within the area of length $L_{x c}(t)$ and width $h$, where $L_{x c}(t)$ is the contact length in the longitudinal direction at time $t$. Thus the resultant force "moves" with the geometric space $\Sigma$ (Fig. 7) and fluctuates with the variations of the road texture during rolling.
The resultant forces obtained for the DAC 0/10 (old) at 30,40 and $50 \mathrm{~km} / \mathrm{h}$ are represented in Fig. 8 (a). The same signals are plotted in Fig. 8 (b) using $V t$ instead of $t$ as a variable. In this case, it appears that
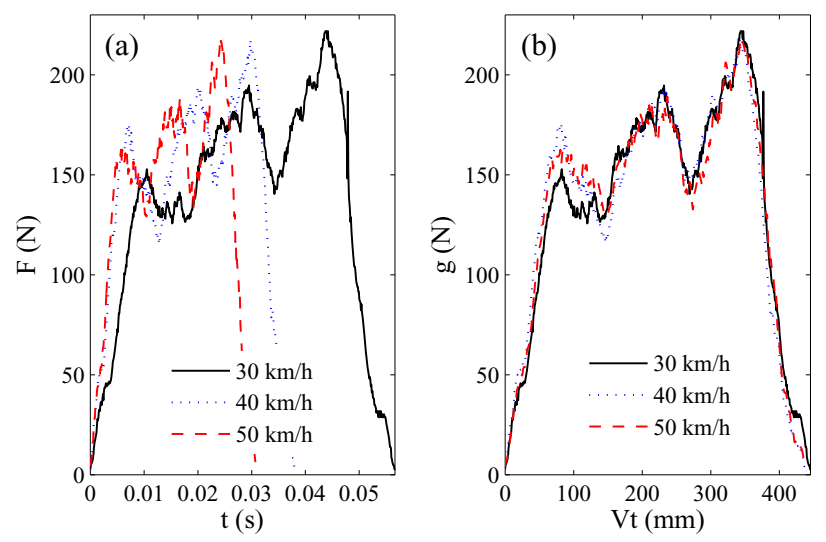

Figure 8: "Longitudinal tests" for the DAC 0/10 (old):

(a) Contact forces $F(t)$, (b) Functions $g(V t)$.

the signals are very similar for the three rolling speeds. The same observation was made for the other five road surfaces. Thus the measured contact forces could be mainly influenced by the position $X=V t$ of the tyre on the road, i.e. by the road texture. This is investigated in the following by studying the root-mean-square (rms) resultant forces and the spectral content of the signals at different speeds.

If the contact forces are mainly influenced by the road texture, then the resultant force $F_{i}$ at speed $V_{i}$ can be written as an invariant function $g$ of the variable $V_{i} t$ :

$$
\forall t \in\left[0, T_{i}\right], \quad F_{i}(t)=g\left(V_{i} t\right)
$$

where $t_{0}=0$ is the instant when the tyre enters onto the active line of cells and $T_{i}$ is the time when the tyre leaves it at speed $V_{i}$. Then under the assumption of Eq (3) the rms resultant force $F_{r m s, i}$ at speed $V_{i}$ satisfies:

$$
F_{r m s, i}=\sqrt{\frac{1}{V_{i} T_{i}} \int_{0}^{V_{i} T_{i}}|g(X)|^{2} d X}
$$

Additionally the length $L=V_{i} T_{i}$ remains invariant with the speed due to the fact that the tyre always crosses the same finite length of the active line of cells:

$$
\forall V_{i}, \quad V_{i} T_{i}=L
$$

Introducing the relation of Eq (5) into Eq (4) gives:

$$
F_{r m s, i}=\sqrt{\frac{1}{L} \int_{0}^{L}|g(X)|^{2} d X}=g_{r m s}
$$

where $g_{r m s}$ is the rms value of function $g$ and should be invariant with speed due to the fact that the tyre always crosses the same profile of the road texture for the three tests at different speeds. Thus for a given road surface the rms resultant forces $F_{r m s, i}$ should be the same at different speeds. Also for the six tested road surfaces, the rms resultant forces $F_{r m s, i}$ were calculated from the measured signals. The values of $F_{r m s, 30}$ and $F_{r m s, 50}$ 


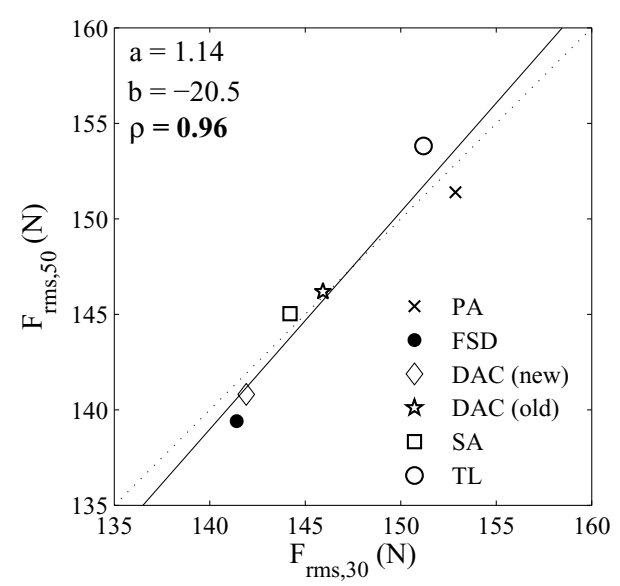

Figure 9: Comparison of $F_{r m s, 30}$ and $F_{r m s, 50}$.

obtained respectively at 30 and $50 \mathrm{~km} / \mathrm{h}$ are compared in Fig. 9. The data from the six road surfaces were considered and a linear fitting was performed. This gives a regression line (in plain line) which coefficients $a$ and $b$ are given in the top left. A good agreement between the rms forces was found as attested by the value of the correlation coefficient $\rho$ very close to one. The same kind of results was obtained when comparing the rms forces at 30 and $40 \mathrm{~km} / \mathrm{h}$ and at 40 and $50 \mathrm{~km} / \mathrm{h}$.

Another consequence of Eq (3) is that the Fourier transform $\hat{F}_{i}$ of the force $F_{i}$ at speed $V_{i}$ should be linked to the Fourier transform $\hat{g}$ of the function $g$ by:

$$
\hat{F}_{i}(f)=\frac{\hat{g}\left(f / V_{i}\right)}{V_{i}}
$$

where $f$ is the frequency. Then from Eq (7) the Fourier transform of a force $F_{r}$ at a reference speed $V_{r}$ and the one of a force $F_{i}$ at a speed $V_{i}$ are linked by:

$$
V_{r} \hat{F}_{r}(f)=V_{i} \hat{F}_{i}\left(f V_{i} / V_{r}\right)
$$

Additionally the spectral levels $L_{F, i}$ of the contact force measured at the speed $V_{i}$ are calculated as follows:

$$
L_{F, i}(f)=20 \log _{10}\left(\frac{\left|\hat{F}_{i}(f)\right|}{F_{0}}\right)
$$

where $\left|\hat{F}_{i}(f)\right|$ is the modulus of $\hat{F}_{i}(f)$ and $F_{0}=10^{-3} \mathrm{~N}$ is a reference force value. Then the modified spectral levels $L_{F, i}^{*}$ at speed $V_{i}$ are defined by:

$$
L_{F, i}^{*}(f)=L_{F, i}(f)+20 \log _{10}\left(V_{i}\right)
$$

Finally, from Eqs (8) and (10) the following relation should be verified under the assumption of Eq (3):

$$
L_{F, r}^{*}(f)=L_{F, i}^{*}\left(f V_{i} / V_{r}\right)
$$

The modified spectra $L_{F, i}^{*}\left(f V_{i} / V_{r}\right)$ at 30,40 and 50 $\mathrm{km} / \mathrm{h}$ are given in third octave bands levels in Fig. 10 for the DAC 0/10 (old). The reference speed $V_{r}$ is 30 $\mathrm{km} / \mathrm{h}$ and the levels are represented between 100 and $2500 \mathrm{~Hz}$. The results are quite different both in terms of shape and amplitude. Some similarities can be observed below $315 \mathrm{~Hz}$, especially for the signal at $40 \mathrm{~km} / \mathrm{h}$ and $50 \mathrm{~km} / \mathrm{h}$. However the levels at the different speeds are significantly different at frequencies above $315 \mathrm{~Hz}$. Similar results were obtained for the other road surfaces.

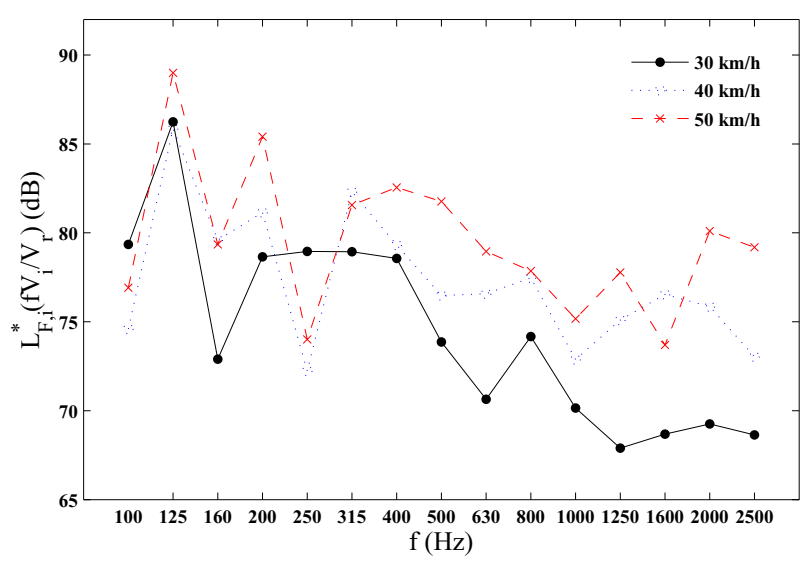

Figure 10: Modified spectra $L_{F, i}^{*}$ in third octave bands levels for the DAC 0/10 (old) with $V_{r}=30 \mathrm{~km} / \mathrm{h}$.

\subsection{Discussion}

The results obtained from the measurements of the dynamical contact stresses can be summarized as follows:

1. The contact area in rolling conditions remains almost constant with speed and is $20 \%$ smaller than the one measured in statics.

2. The rms resultant force for the "longitudinal tests" is almost invariant with speed.

3. The force spectra for the "longitudinal tests" vary widely with speed, especially for frequencies above $315 \mathrm{~Hz}$.

4. At a given speed, the force spectra are widely influenced by the road texture, as attested in Fig. 11 by the mean spectra of the resultant force measured at $30 \mathrm{~km} / \mathrm{h}$.

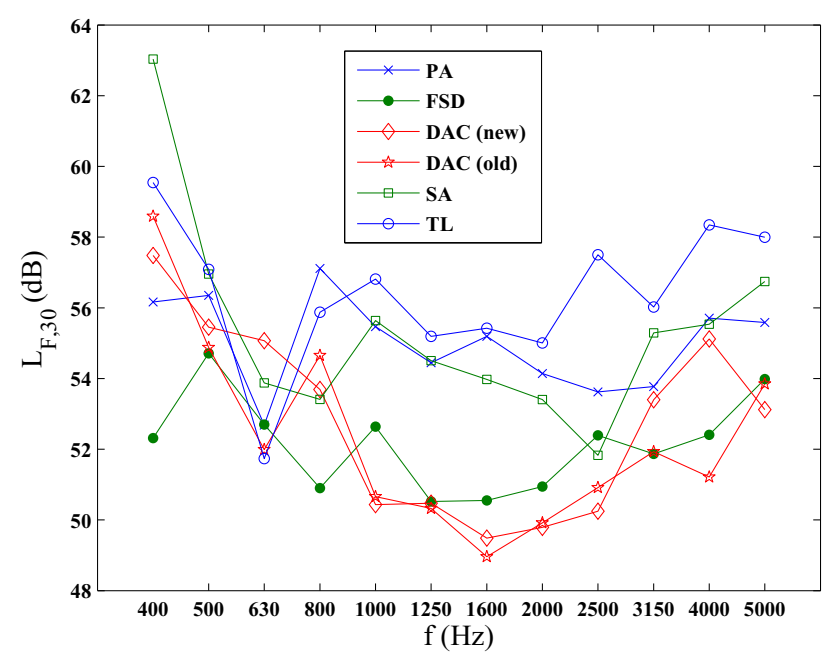

Figure 11: Mean spectra of the resultant force measured at $30 \mathrm{~km} / \mathrm{h}$ for the six road surfaces.

Result 1. can be due to the centrifugation of the tyre belt during rolling and to the dynamical material properties of tyre compounds. However, no significant decrease of the contact area was observed with increasing speed. Then in this study the stiffening of the tread due to centrifugation related in [12] doesn't have a significant effect on the contact areas within the studied rolling 
speeds. Also the decrease of the contact area in rolling conditions could be more explained by the viscoelasticity of the rubber of the tyre tread. This behavior tends to make the material stiffer when rolling which may give smaller contact areas in dynamics. The viscoelasticity is also responsible for a shift between the strains and the stresses applied at the surface of the tyre. In statics the rubber of the tread can creep longer than in dynamics, giving higher contact areas in the first case.

Results $2 ., 3$. and 4 . are related to tyre/road interaction during rolling. Result 2 . on the rms contact forces and result 4 . on the spectral contents of the contact forces at a given speed show that the geometry of the road surface (shape, size and distribution of the asperities) has a great influence on tyre/road contact, especially on the spectral content of the signals. Additionally, result 3 . can be due to the vibration of the tyre tread during rolling, especially the bending waves which can modified the contact stresses when the wavelength associated with the vibrations in the tyre is small in comparison with the dimensions of the contact patch.

\section{Conclusions}

This study is a first approach to experimentally investigate the tyre/road contact stresses in rolling conditions within the framework of tyre/road noise. In situ measurements of contact stresses have been performed for a slick tyre rolling on six different road surfaces between 30 and $50 \mathrm{~km} / \mathrm{h}$. The resulting database has been used to investigate the effects of the road texture and of the tyre behavior on the dynamical contact forces.

The dynamical contact patches obtained from the "transverse tests" show a decrease in the order of 20 percents of the contact area in rolling conditions in comparison with the one measured in statics. This result could be due to the dynamical properties of tyre compounds, like the viscoelasticity of the rubber. Concerning the "longitudinal tests", the rms value of the resultant force was almost invariant with speed for the whole tested road surfaces. At a given speed, the force spectra from different road surfaces are significantly different, which shows a great influence of road texture on contact. For a given road surface, the force spectra varied widely with speed, due to the vibration of the tyre tread.

These experimental conclusions could be used to improve the existing tyre/road contact models. First a realistic description of the road surface is needed, which is already the case in most of the deterministic or hybrid models given in references. Then the tyre behavior has to be included in the contact model. This is already the case in Refs. $[2,3,5,6]$ where the vibrations of a tyre model including frequency dependent storage and loss modulus of material compounds are coupled with the contact conditions for the calculation of contact forces. Finally, the introduction of viscoelasticity and tyre vibrations is in progress in the contact model developed by the authors (Refs. [8, 9]).

\section{References}

[1] U. Sandberg, "Tyre/road noise - Myths and realities", Proc. of Internoise 2001, The Hague, The Netherlands, August 2001

[2] W. Kropp, "Ein Modell zur Beschreibung des Rollgeräusches eines unprofilierten Gürtelreifens auf rauher Strassenoberfläche", $\mathrm{PhD}$ Thesis, T.U. Berlin, 1992

[3] J.-F. Hamet, P. Klein, "Road texture and tire noise", Proc. of Internoise 2000, Nice, France, August 2000

[4] P. Klein, J.-F. Hamet, F. Anfosso-Lédée, "An envelopment procedure for tire/road contact", Proc. of SURF 2004, Toronto, Canada, June 2004

[5] K. Larsson, "Modelling of dynamic contact - Exemplified on tyre/road interaction", PhD Thesis, Chalmers Univ. of Tech., Göteborg, Sweden, 2002

[6] F. Wullens, W. Kropp, "A three-dimensional contact model for tyre/road interaction in rolling conditions", Acta Acustica 90, 702-711 (2004)

[7] T. Fujikawa, H. Koike, Y. Oshino, H. Tachibana, "Definition of road roughness parameters for tire vibration noise control", Applied acoustics 66, 501$512(2005)$

[8] A. Sameur, "Modèle de contact pneumatique/chaussée pour la prévision du bruit de roulement", PhD thesis, École Nationale des Ponts et Chaussées, 2004

[9] J. Cesbron, "Influence de la texture de chaussée sur le bruit de contact pneumatique/chaussée", PhD Thesis, École Centrale de Nantes/Univ. de Nantes, 2007

[10] M. Brinkmeier, U. Nackenhorst, S. Petersen, O. von Estorff, "A finite element approach for the simulation of tire rolling noise", Journal of Sound and Vibration 309, 20-39 (2008)

[11] J. Périsse, " A study of radial vibrations of a rolling tyre for tyre-road noise characterisation", Mech. Systems and Signal Proc. 16, 1043-1058 (2002)

[12] P. Kindt, F. De Coninck, P. Sas, W. Desmet, "Test setup for tire/road noise caused by road impact excitations: first outlines", Proc. of ISMA 2006, Leuven, Belgium, Sept. 2006, pp.4327-4336

[13] Tekscan, Inc. I-Scan Pressure Measurement System - User Manual, Version 5.7x. South Boston, 2005 